\title{
Rethinking teaching and teachers: Bringing content back into conversation
}

\author{
Zongyi Deng* - National Institute of Education, Nanyang Technological \\ University, Singapore
}

\begin{abstract}
The question of content - that is, knowledge in the curriculum - has all but disappeared from global policy and academic discourses concerning teaching and teachers. Invoking the work of Michael Young and his colleagues concerning 'bringing knowledge back in', Bildung-centred Didaktik, and Joseph J. Schwab's curriculum thinking, this article attempts to bring content back into the conversation on teaching and teachers. The discussion yields an educational, curricular understanding of teaching and teachers by making three arguments. First, teaching (content) is an 'intergenerational' task vital for social reproduction and innovation. Second, teaching, by way of a meaningful encounter between content and students, contributes to their self-formation and the development of human powers and dispositions. Third, teaching is a practical, interpretive act that calls for curriculum thinking that is centred on the 'what' (content) and 'why' (purpose) of teaching.
\end{abstract}

Keywords: teaching; teachers; content; curriculum theory; Didaktik

\section{Introduction}

Content - knowledge in the curriculum - is an indispensable element in talking and thinking about classroom teaching. In common language, the term 'teaching' means the imparting of content or knowledge. In the German Didaktik tradition, teaching is conceptualized by way of the Didaktik triangle - comprised of three general, essential elements: content, teacher and student. In US curriculum theory, teaching is construed as consisting of four indispensable, and equally important, curriculum commonplaces: subject matter (content), teacher, learner and milieu (Schwab, 1973).

However, content as a topic of discussion has disappeared from current global policy discourse concerning teaching and teachers. Across the globe there has been a shift in curriculum policy from a concern with content selection and organization to a preoccupation with academic standards, learning outcomes and high-stakes testing (Yates and Collins, 2010; Young, 2009a). Accompanying that shift is a move to depict teaching as focused on promoting students' academic outcomes measured by highstakes tests, and teachers as accountable for students' learning outcomes, through the employment of evidence-based practices (Hopmann, 2008).

The omission of content, too, is evident in the current popular discourse on teaching and teachers within the academic education community - promoted by a new 'language of learning' - a discourse also widely adopted by education policymakers in different parts of the world (Biesta, 2005). In that discourse, teaching is construed as the facilitation of learning that is constructivist and learner-centred, and the teacher 
as one who no longer passes on content (knowledge) to learners but who instead supports and facilitates the learning process (Biesta, 2005, 2010).

In the academic literature on teaching and teachers, content is also the least discussed commonplace. Much of the discussion on teachers has centred on teachers' characteristics, self, identity, agency, learning and professional development. Most discourse on teaching has focused on instructional strategies and models, the student-teacher relationship, the context in which teaching takes place (classroom, school, national, international or global), the social and political nature of teaching, and instructional policy and reform (see Saha and Dworkin, 2009; Biddle et al., 1997). When content is discussed, it is often treated as something to be transferred to or constructed by students, apart from a concern for the broader purpose of education (see Deng, 2018b).

This article attempts to reintroduce content into the conversation on teaching and teachers through revisiting the recent work of Michael Young and his colleagues concerning 'bringing knowledge back in' (for example, Young, 2008; Young et al., 2014; Young and Muller, 2015) as well as Bildung-centred Didaktik and Joseph J. Schwab's curriculum thinking. The recent work of Young and his colleagues is examined because their work has important things to say about teaching and teachers in the light of the distinctive function of schooling - the transmission of disciplinary knowledge that students cannot acquire at home. Bildung-centred Didaktik and Schwab's curriculum thinking are discussed because these two models or theories provide important insights into teaching and teachers from the perspective of education as the cultivation of human powers and dispositions in and through content. The examination of these three schools of thought, as will be seen, yields an educational, curricular understanding of teaching and teachers that goes far beyond what current policy and academic discourses can capture.

\section{Bringing knowledge back in}

Over the last ten years, Michael Young and his colleagues have embarked on a project of 'bringing knowledge back in' to the recent global discourse on curriculum policy and practice (e.g. Young, 2008; Young et al., 2014; Young and Muller, 2015). Informed by social realism and based on the works of Émile Durkheim and Basil Bernstein, they develop a social-realist theory of knowledge that differentiates between academic, disciplinary and everyday knowledge, and, further, between different types of disciplinary knowledge. While reflecting human interests or standpoints, disciplinary knowledge has its own properties, trustfulness and explanatory power (see Young, 2008). Created by specialist communities of scholars, it is powerful knowledge because it provides the best understanding of the natural and social worlds. The acquisition of this knowledge facilitates the imagining of alternatives and enables people to move beyond their particular experience (Young and Muller, 2013). As such, disciplinary knowledge is worthy of being taught in its own right and to its own end.

With this theory of knowledge as an essential point of departure, Young and his colleagues argue that the central purpose of schooling is to help students gain access to disciplinary knowledge that they cannot acquire at home (Young, 2009b). Furthermore, access to this knowledge is an entitlement of all students - and (thus) a social justice issue. After all, this purpose is essential if we are to enable the next generations to create new knowledge based on existing knowledge. As will be argued in the last section of this article, it imbues the task of teaching and the responsibility of a teacher with intergenerational significance. In this connection, curriculum planning 
is a process of recontextualizing an academic discipline into a school subject - which entails selecting, sequencing and pacing academic knowledge in view of the coherence of the discipline and the constraints created by the developmental stages of students. The differentiation of different forms of disciplinary knowledge and clarification of their inherent structures provide a necessary basis for curriculum planning that is geared to the effective transmission of disciplinary knowledge (Young, 2013).

Accordingly, teaching is viewed as a process of passing on a body of disciplinary knowledge that students cannot acquire at home. The central task of a teacher is to promote epistemic access to disciplinary knowledge and to take students beyond their existing experience or what they already know (Young et al., 2014). To do this, the teacher needs to interpret the national curriculum to identify what knowledge is powerful for students at different ages, in light of the central purpose of schooling the why of teaching - with a view to creating educational encounters in the classroom. As such, teachers need to have a theory of the curriculum - a theory of the knowledge students must acquire at various grade levels - in addition to disciplinary knowledge and general pedagogical knowledge (Young et al., 2014).

In short, by way of a social-realist theory of knowledge, Young and his colleagues have contributed to bringing knowledge back into the conversation on teaching and teachers. However, there are two issues. With an exclusive focus on the internal properties and explanatory power of knowledge, they take knowledge as being an end in itself, rather than as a means to some larger purpose of education. They seem to be concerned with, borrowing from David Hamilton, the immediate, present question of 'what should they [students] know?', rather than the future-oriented question of 'what should they [students] become?' (Hamilton, 1999: 136). Another issue, related to the first, concerns the focus of their discourse - knowledge rather than content. As alluded to earlier, content results from institutional curriculum making - a special selection and organization of knowledge for the school curriculum - that takes place prior to and independent of classroom teaching (Karmon, 2007; also see Deng, 2009). Such content constitutes the locus of classroom teaching: it frames a teacher's practice and perspective on teaching (ibid.).

These two issues, overall, have to do with the theoretical underpinnings sociological rather than curricular and educational - of the work of Young and his colleagues. As I have indicated elsewhere, Young and his associates have ignored two bodies of literature - one on curriculum theory and the other on Didaktik - that examine the role of knowledge and content in education, curriculum making and classroom teaching from educational and curricular perspectives (Deng, 2015). As such, they have lost touch with deeper questions about educational purpose, content and teaching that 'have animated pedagogics and didactics' (Hamilton, 1999: 136) - and curriculum theory as well.

\section{Bildung-centred Didaktik}

There are many models or branches of Didaktik in Germany and German-speaking countries, such as Bildung-centred Didaktik (Bildungstheoretische Didaktik), Berliner Didaktik and psychological Didaktik, experimental Didaktik, dialectical Didaktik and so on. This article focuses on Bildung-centred Didaktikbecause it provides a sophisticated, elaborate theoretical account of content in relation to education, curriculum planning and classroom teaching. It has also been 'at the centre of most school teaching and teacher education in Continental Europe' (Hopmann, 2007: 109). 
Bildung-centred Didaktik provides a theory of teaching and learning that pertains to implementing the state curriculum in classrooms. Central to it are the concept of Bildung and a theory of educational content. Standing for the German ideal of (liberal) education, Bildung refers to the formation of the full individual, the cultivation of human powers, sensibility, self-awareness, liberty and freedom, responsibility and dignity (von Humboldt, 2000; also see Hopmann, 2007). The concept is later extended to include the development of self-determination (autonomy), co-determination (participation) and solidarity (Klafki, 1998). Bildung is achieved through linking the self to the world (social and natural) in 'the most general, most animated and most unrestrained interplay' (von Humboldt, 2000: 58). The world, independent from us, is processed by human thought represented by academic disciplines (Lüth, 2000).

With this concept of Bildung as a point of departure, German Didaktikers conceive of the role of disciplinary knowledge in relation to education and curriculum. Knowledge is to be 'used in the service of intellectual and moral Bildung' (Lüth, 2000: 77), rather than something that is to be gained for its own sake. Academic disciplines are an indispensable resource or vehicle for Bildung (Klafki, 2000). There are several forms of disciplinary knowledge - historical, social, linguistic, geographic, physical, chemical and biological - each of which gives us access to a particular aspect of reality and each of which has potential to cultivate a particular type of human power and disposition (Weniger, 2000).

Furthermore, German Didaktikers established a theory of educational content (Theorie der Bildungsinhalte) that serves to inform curriculum planning and classroom teaching for Bildung. It consists of four related concepts: contents of education (Bildungsinhalt), educational substance (Bildungsgehalt), the elemental (das Elementare) and the fundamental (das Fundamentale). Curriculum designers characteristically call the contents embodied in the state curriculum the 'contents of education' which result from a deliberative process of selection and organization of the wealth of the academic knowledge, experience and wisdom for Bildung:

Curriculum designers assume that these contents, once the children or adolescents have internalized and thus acquired them, will enable the young people to 'produce a certain order' (Litt) in themselves and at the same time in their relation to the world, to 'assume responsibility' (Weniger), and to cope with the requirements of life. The contents of teaching and learning will represent such order, or possibilities for such order, such responsibilities, inevitable requirements and opportunities.... (Klafki, 2000: 150)

In other words, such content is seen as embodying educational potential - in terms of potential impact on or contribution to self-formation and the development of human powers and dispositions. Furthermore, such potential exists in the educational substance of content comprised by the elemental - concentrated, reduced content in the form of penetrating cases, concepts, principles, values and so on. The fundamental refers to the 'primordial' experience that the elemental can bring out or the potential impact it can have on the perspectives, modes of thinking, dispositions and ways of being-in-the-world of individuals (Krüger, 2008).

Informed by the theory of educational content, the state curriculum framework only lays out school subjects and their contents to be covered in schools, but does not specify the educational substance, meaning and significance of content - these are to be identified and interpreted by a teacher in a specific classroom situation (Hopmann, 2007). Teachers are entrusted with a high level of professional autonomy to interpret 
the state curriculum framework. They are viewed as curriculum makers 'working within, but not directed by' the state curriculum framework, informed by the idea of Bildung and the Didaktik way of thinking (Westbury, 2000: 26).

With reference to the notion of Bildung and the theory of educational content, German Didaktikers articulate what teaching is and what responsibility a teacher needs to have. Classroom teaching is seen as a 'fruitful encounter' between content and the learner for Bildung (Klafki, 2000), rather than as the mere transmission of academic content. Such an encounter leads to a deeper understanding of the world, modifications in perspectives and the cultivation of human capacities or powers. Students are seen as unique individuals, with their own experiences, motivations and interests. Therefore, in instructional planning, the teacher must identify the elemental aspects of content (penetrating cases, basic ideas, concepts and methods) and ascertain the value and significance of content with reference to individual students 'with a particular human context in mind, with its attendant past and its anticipated future' (Klafki, 2000: 148). Furthermore, they are to transform content into forms that are perceived as meaningful by students themselves.

To support this vision of instructional planning, Klafki formulated a five-step set of questions to assist teachers in exploring the educational potential of content and its actualization:

1. What wider or general sense or reality does this content exemplify and open up to the learner? What basic phenomenon or fundamental principle, what law, criterion, problem, method, technique, or attitude can be grasped by dealing with this content as an 'example'?

2. What significance does the content in question, or the experience, knowledge, ability or skill, to be acquired through this topic, already possess in the minds of the children in my class? What significance should it have from a pedagogical point of view?

3. What constitutes the topic's significance for the children's future?

4. How is the content structured (which has been placed in a specifically pedagogical perspective by questions 1,2 and 3 )?

5. What are the special cases, phenomena, situations, experiments, persons, elements of aesthetic experience, and so forth, in terms of which the structure of the content in question can become interesting, stimulating, approachable, conceivable or vivid for children of the stage of development of this class? (2000: 151-7)

Questions 1, 2 and 3 concern the substance (that is, the elemental) and potential of content in terms of what should be taught, what the content signifies and why it is significant for students. Questions 4 and 5 deal with the means of teaching the content and actualizing its educational potential in terms of content structure and pedagogical representations.

\section{Schwab's curriculum thinking}

As with Didaktik, there are not one but many schools of US curriculum theory or thinking, for example technological, deliberative, critical, postmodernist, post-structuralist and so forth. Here I focus on Schwab's curriculum thinking because he is one of the very few US theorists who provides a sophisticated, elaborate account of content in terms of both education and curriculum. His thinking is deeply embedded in, and shaped by, the Chicago tradition of liberal education associated with Robert Hutchins, John Dewey, Richard McKeon and Donald Levine, among others (Levine, 2006). 
Central to his curriculum thinking is a vision of a liberal education, a theory of knowledge for the kind of liberal education he envisages and a theory of content that serves to inform curriculum planning and move classroom teaching towards that vision. For Schwab, the central purpose of liberal education, which is akin to Bildung, is the development of an empowered, autonomous and active individual. Such an individual possesses an understanding of culture and the world, and a set of powers and dispositions that allows them to face the challenges and problems in the society of their times. The powers and dispositions of an educated person, further articulated by Schwab, include a 'capacity for "syntactical communication"', a disposition to 'quest, beyond mere survival, for a state called "happiness"', an ability to 'deliberate wisely about technologies based on science' and 'to choose thoughtfully among several technological methods' (Levine, 2006: 119). The powers also include 'abilities and insights to face the new problems of our times and to use the new instrumentalities with wisdom and freedom' (McKeon, 1953: 113) and 'critical and organising power and deliberative command over choice and action' (Schwab, 1978: 125), among others. The cultivation of such intellectual, social and civic powers and dispositions is achieved through the interaction of individual students with various forms of knowledge embodied in contemporary academic disciplines.

The primary concern of Schwab, like that of the German Didaktikers, is with the contribution of academic disciplines to human formation and the cultivation of human powers and dispositions, rather than the epistemological properties, structures and explanatory powers of disciplinary knowledge per se (see Fenstermacher, 1980). Accordingly, Schwab articulates a theory of knowledge that conceives of the essence of academic disciplines in ways that are productive in cultivating those human powers and dispositions. Following McKeon, he identifies three types of academic disciplines - natural sciences, social sciences and humanities - each of which has the potential to develop a particular type of human power and disposition. The significance of each discipline is determined by a distinct set of arts or methods of inquiry instead of content or subject matter. As Levine explains:

the place of the natural sciences in general education was determined by the arts required to analyse problems, validate knowledge, and communicate statements about natures and things. The place of social sciences in general education was determined by the arts required to deal with problems concerning associations set up by humans to achieve common values. The place of the humanities in general education was determined by the arts required to analyse the great achievements and products of human creativity when considered with respect to their formal structure. (2006: 99)

In this connection, Schwab argues that the contribution of an academic discipline to the cultivation of human powers lies in the methods or arts of inquiry embedded within the discipline. An academic discipline consists not only of statements and conclusions, but also arts or methods employed in disciplinary inquiry, an understanding of which enables the development of liberating human powers that are applicable in wideranging situations and practices:

The 'intellectual' arts and skills with which the liberal education curriculum is concerned are not then intellectual as to subject matter, and thus exclusive of other subject matters, but intellectual as to quality. They are the arts and skills which confer cogency upon situations and actions 
whether these be scientific, social, or humanistic, general and abstract or particular and concrete. The liberal arts, however formulated, are to be understood as the best statement of our present knowledge of the human make, of various means - some special in their application to specific subject matters, some general - by which the understanding frees us from submission to impressions, beliefs, and impulses, to give us critical and organizing power and deliberative command over choice and action. A liberal curriculum is one concerned that its students develop such powers. (Schwab, 1978: 125)

Consistent with this theory of knowledge, Schwab formulated a theory of content that serves to inform curriculum planning and classroom teaching. This theory consists of a particular notion of content and a set of categories that could serve to reveal the educational potential of content for the cultivation of human powers. Identified from the fund of academic knowledge, it takes the form of scholarly materials (histories, scientific reports, literacy works and so on) that reflect the revisionary character of knowledge (concerning how knowledge was developed) rather than just the 'rhetoric of conclusion' (knowledge as a final product) (Schwab, 1962). The set of categories, called three faces, is explained as follows:

- The first face is the purport [educational meaning and significance] conveyed by the material, referring to, for instance, an account of a political event by a historical segment [an extract from a historical source], a way of classifying physical phenomena by a scientific report, a moral dilemma or an image of a person by a literary work. Having students encounter the purport as such can open up opportunities for widening their horizons, transforming their perspectives, and cultivating their moral sensitivity.

- The second face is the originating discipline from which scholarly material derives, referring to a coherent way of inquiry - a problem identified, an investigation executed, the data or argument sought and a conclusion reached. Having students understand and experience the problem, method, principle and conclusion of a disciplinary inquiry can give rise to the development of independent critical thinking, an ability to judge the validity and reliability of knowledge claims, and an understanding of the merits and limitations of a particular mode of inquiry.

- The third face refers to access disciplines that can be brought to bear on scholarly material to disclose its full complication and sophistication. When a piece of material is scrutinised by asking different types of questions, using different perspectives and different methods of inquiry, it can render diverse opportunities for cultivating critical thinking, freedom of thought, self-understanding and prudent thought and action. (Deng, 2018a: 342-3; also see Schwab, 1973)

Informed by this theory of content, curriculum planning entails a deliberative and interpretive process of selecting the content from academic disciplines with a view to their educational potential, within a particular instructional context and with a particular group of learners in mind. The process entails identifying the educational potential of the scholarly material under consideration, by means of the three faces purport, originating discipline and access disciplines. The final decision to include a particular piece of scholarly content in the curriculum is made with reference to both its educational potential and the four curriculum commonplaces: subject matter, milieus, learner and teacher (Schwab, 1973). 
What teaching is, and what responsibility teachers need to have, take on a special meaning in regard to the vision of a liberal education, the theory of knowledge and the theory of content. As with Didaktik, classroom teaching is seen as an encounter between students and content to achieve the kind of education envisioned. A student is seen as a unique individual, with eros ('the energy of wanting'), and as an instrument that the teacher needs to make use of (Schwab, 1978). In instructional planning, the teacher is to recover the significance in scholarly material through 'arts of recovery' - in terms of the meaning conveyed (the purport), the particular way of inquiry involved (the originating discipline) and multiple ways of inquiry brought forth (access disciplines) which could be brought to bear on the material (Schwab, 1969). By means of these three categories, scholarly material or a text is made to open up manifold opportunities for challenging the understanding of students and cultivating their intellectual and moral powers and dispositions.

\section{Theorizing content, teaching and teachers: Comparison and contrast}

Despite being developed in different social, historical and cultural milieus, Bildungcentred Didaktik and Schwab's curriculum thinking have significant similarities with respect to theorizing teaching and teachers. Both employ, as a point of departure, a vision of education - centred on the cultivation of human powers and dispositions - for thinking about the role of knowledge in education and curriculum. Both treat disciplinary knowledge, not in and of itself, but as a resource or vehicle for that cultivation. Both view content that results from the deliberate selection of academic knowledge as embodying educational potential. Both see classroom teaching as an educational encounter or meeting between students and content, and stress the necessity of unlocking the educational potential of content for cultivating human powers and dispositions.

There are, of course, differences between Bildung-centred Didaktik and Schwab's curriculum thinking. The former views the cultivation of human powers and dispositions as resulting from interactions not only with academic knowledge but also with society and culture, whereas the latter conceives of it as resulting primarily from interactions with disciplinary knowledge. The former views academic disciplines as established bodies of knowledge, whereas the latter sees them in terms of achievements as well as, more importantly, arts or methods of inquiry.

Differences aside, both Bildung-centred Didaktik and Schwab's curriculum thinking are markedly different from that of Young and his colleagues. The latter employs a sociological theory of knowledge - rather than a vision of education as their point of departure for thinking about the purpose of education, curriculum planning and classroom teaching. Disciplinary knowledge is viewed as having its own powers, worthy of being taught for its own sake or to its own end. Classroom teaching is seen as a process of transmitting disciplinary knowledge to students.

Behind these similarities and differences are two rather different types of educational theorizing that are associated with two distinctive traditions of educational thinking. Both Bildung-centred Didaktik and Schwab's curriculum thinking exemplify a way of theorizing in the European Pädagogik tradition which is distinctively educational, normative and hermeneutic. (For an explanation on the convergence in educational theorizing between Schwab and Didaktikers, see Künzli, 2013 and Reid, 1980.) This way of theorizing is educational because it is centrally concerned with questions pertaining to human formation and development. It is normative because the theorizing is 
informed by a conception of what education ought to be. Furthermore, both Bildungcentred Didaktik and Schwab's curriculum thinking have a strong hermeneutic and interpretive inclination, a proclivity towards interpreting and unpacking the meaning and significance of content by means of a set of categories. After all, the European tradition seeks to establish Pädagogik as a distinctive human science with 'its own terminology, its own points of departure, its own methods of investigation and verification' (Krüger, 2008: 216).

By contrast, the way of theorizing used by Young and his colleagues reflects the Anglophone disciplines of education tradition in which the perspectives or theories that are used to think about education are derived or developed from theories of foundational disciplines (psychology, sociology, philosophy and history) (Furlong and Whitty, 2017). Such perspectives or theories are then used to establish theoretical principles concerning curriculum planning and classroom teaching. The tradition has a strong dependency on foundational disciplines for its language, theoretical perspectives and methods.

\section{Conclusion: Towards an educational and curricular understanding of teaching and teachers}

This article is concerned with the disappearance of content in current global policy and academic discourses concerning teaching and teachers. These two discourses, as noted at the start, have been respectively shaped by the accountability movement, which reduces teaching to the promotion of students' academic outcomes through evidence-based practices, and a language of learning that reduces teaching to the facilitation of learning. Invoking the recent work of Michael Young and his colleagues, Bildung-centred Didaktik and Schwab's curriculum thinking, in this article I attempt to bring content back into the conversation on teaching and teachers. In view of the above discussion, I now present three arguments that seek to move beyond current policy and academic discourses, and towards an educational and curricular understanding of teaching and teachers.

The first argument is that teaching (content) is an intergenerational task vital for social reproduction and innovation. Teaching, according to Biesta (2012: 36), 'is always framed by a telos - that is, by a sense of purpose - which means that teachers always need to make judgements about what is desirable in relation to the different purposes that frame their practice'. As noted earlier, according to Young and his colleagues, the central purpose of schools is the transmission of a body of disciplinary knowledge that allows students to move beyond their particular experience, envisage alternatives and participate in social and political debates. This purpose is also vital for enabling the next generations to create new knowledge built on existing knowledge. Therefore, by passing on disciplinary knowledge to students, a teacher contributes to the process of social reproduction and change, that is 'reproducing human societies' and 'providing the conditions which enable them to innovate and change' (Young, 2009b: 10).

This distinct purpose of schooling calls for teachers to make deliberate, wellinformed decisions on what 'powerful' knowledge or content they want all their students to have access to. This requirement is inextricably connected with the ethical responsibility of a teacher which is aptly captured by the intergenerational question: 'What does the older generation want with the younger?', first raised by the German philosopher Friedrich Schleiermacher (1768-1834). Concerning this question, Uljens and Ylimaki (2017: 28) observe that 'Teaching ... is about dealing with how to live out our responsibility to support the student's stepwise development toward an independent 
cultural being and citizen able to participate in common tasks of the society, culture, politics and economy [labour market].' Furthermore, Friesen argues that the ethical responsibility of teachers with regard to Schleiermacher's question takes on greater significance in the current world:

we must prepare them to inherit the world we have helped to create. This is a world characterized by rapid change, radical uncertainty and sometimes rabid competition, but it is also one that can be secured by ties of family, love, identity and belonging. It is also a world where adults and previous generations have made irreversible decisions regarding the lives of children and future generations. In this sense too, we adults want - or have in effect demanded - something from them. (2017: 7)

In view of this, thinking of teachers and teaching in terms of learning or via the learning discourse 'simply darkens or conceals the question of adult responsibility' and 'distracts and detracts' from Schleiermacher's urgent question of 'why the older generation is doing what it is doing' (Friesen, 2017: 8).

The second argument, closely related to the first, is that teaching, by way of a meaningful encounter between content and students, contributes to their selfformation and the development of human powers. Teaching is an educational intervention that aims to bring about something new, something that has an impact on students. This intervention, for Young and his colleagues, is achieved through passing on a body of disciplinary content that can take students beyond their immediate, surrounding experience. From the perspective of both German Didaktikers and Schwab, the intervention occurs in terms of a student-content encounter that gives rise to opportunities for students to cultivate intellectual, moral and social powers and dispositions. By making such an encounter possible, the teacher 'opens up a world for the student, thus opening the student for the world' (Hopmann, 2007: 115). Teaching, Biesta (2012: 43) observes, involves 'an ongoing dialogue between "self" and "other" [in the widest sense of the word "other"] in which both are formed and transformed - a process through which we come "into the world"... and the world comes into us".

To argue for teaching as an educational intervention is to counter the pervasive, popular learning discourse that reduces teaching to the facilitation of learning and a teacher to a facilitator of learning. A teacher must be positioned as someone who is at the heart of the educational process rather than as someone 'who literally stands at the sideline in order to facilitate the learning of his or her "learners"' (Biesta, 2012: 38).

The third (and last) argument is that teaching is a practical, interpretive act that calls for curriculum thinking that is centred on the 'what' (content) and 'why' (purpose) of teaching. Teaching is a practical endeavour because a teacher works with specific content, specific students and specific materials in a specific classroom context (Schwab, 2013). It is also an interpretive act because it involves content (in the form of curriculum texts) that must be interpreted and acted upon by a teacher to an educational end. For Young and his colleagues, a teacher necessarily identifies what powerful knowledge is by interpreting the national curriculum, so as to help students to gain epistemic access to disciplinary knowledge. From the perspective of Didaktik and Schwab, a teacher necessarily interprets the content in the institutional curriculum, identifying its elemental elements and ascertaining the educational potential of content for developing human powers and dispositions. In both cases, the interpretation calls for a special kind of curriculum thinking that is centred on the 'what' and 'why' of teaching - that is, on the content and purpose questions. In this regard, a teacher can be seen as a 'curriculum theorist'. Doyle explains: 
Teaching is, at its core, an interpretive process grounded in conceptions of what one is teaching and what value that content has for students and society. And the choices that teachers make with respect to their content have enormous consequences for the lives of students and the health of the society. To teach effectively, teachers much be responsible curriculum theorists. (1992: 77)

In other words, a teacher has an ethical responsibility to reflect on the what and why of education - for which the learning discourse is empty (Biesta, 2012).

These three arguments, overall, outline a curricular and educational contour of the meaning of teaching and being a teacher that goes far beyond what current policy and academic discourses can capture, due to the omission or neglect of the content question. My attempt to bring content back into the conversation on teaching and teachers, I hope, makes it clear that teaching is an ethical and intellectual undertaking that is vital for social reproduction and innovation, human development and the flourishing of students - and for which content is an essential resource. And a teacher, being (as they are) at the heart of such an undertaking, is a curriculum maker (or theorist) who must grapple with the intellectual and moral questions of what content should be taught, why it should be taught and how it should be taught within a particular classroom context.

\section{Acknowledgements}

This article stems from a keynote presentation delivered at the Didactics and Curriculum in Complicated Dialogue seminar, University of Southern Denmark, Odense M, Denmark, 25-26 January 2018. I am very grateful to Professors Ane Qvortrup and Ellen Krogh for the invitation. I also want to thank the two anonymous reviewers for their very useful comments on earlier drafts of this article.

\section{Notes on the contributor}

Zongyi Deng is Associate Professor at the National Institute of Education, Nanyang Technological University, Singapore. He is also an executive editor of the Journal of Curriculum Studies (JCS), the premier international journal in the field of curriculum studies. His areas of interest include curriculum content or subject matter, curriculum theory, didactics (Didaktik), Chinese education and comparative and international education. His publications appear in JCS, Curriculum Inquiry, Comparative Education, Teaching and Teacher Education, the Cambridge Journal of Education, Science Education and other international journals.

\section{References}

Biddle, B.J., Good, T.L. and Goodson, I. (eds) (1997) International Handbook of Teachers and Teaching. Boston: Kluwer Academic.

Biesta, G. (2005) 'Against learning: Reclaiming a language for education in an age of learning'. Nordisk Pedagogik, 25 (1), 54-66.

Biesta, G.J.J. (2010) Good Education in an Age of Measurement: Ethics, politics, democracy. Boulder, CO: Paradigm Publishers.

Biesta, G.J.J. (2012) 'Giving teaching back to education: Responding to the disappearance of the teacher'. Phenomenology and Practice, 6 (2), 35-49.

Deng, Z. (2009) 'The formation of a school subject and the nature of curriculum content: An analysis of liberal studies in Hong Kong'. Journal of Curriculum Studies, 41 (5), 585-604. 
Deng, Z. (2015) 'Content, Joseph Schwab and German Didaktik'. Journal of Curriculum Studies, 47 (6), 773-86.

Deng, Z. (2018a) 'Bringing knowledge back in: Perspectives from liberal education'. Cambridge Journal of Education, 48 (3), 335-51.

Deng, Z. (2018b) 'Pedagogical content knowledge reconceived: Bringing curriculum thinking into the conversation on teachers' content knowledge'. Teaching and Teacher Education, 72, 155-64.

Doyle, W. (1992) 'Constructing curriculum in the classroom'. In Oser, F.K., Dick, A. and Patry, J.-L. (eds) Effective and Responsible Teaching: The new synthesis. San Francisco: Jossey-Bass, 66-79.

Fenstermacher, G.D. (1980) 'The nature of science and its uses for education: Remarks on the philosophical import of Schwab's work'. Curriculum Inquiry, 10 (2), 191-7.

Friesen, N. (2017) 'Mindful practice and hope for the future: Schleiermacher's human education'. Online. www.researchgate.net/publication/320414320 (accessed 18 July 2018).

Furlong, J. and Whitty, G. (2017) 'Knowledge traditions in the study of education'. In Whitty, G. and Furlong, J. (eds) Knowledge and the Study of Education: An international exploration. Oxford: Symposium Books, 13-57.

Hamilton, D. (1999) 'The pedagogic paradox (or why no didactics in England?)'. Pedagogy, Culture and Society, 7 (1), 135-52.

Hopmann, S. (2007) 'Restrained teaching: The common core of Didaktik'. European Educational Research Journal, 6 (2), 109-24.

Hopmann, S.T. (2008) 'No child, no school, no state left behind: Schooling in the age of accountability'. Journal of Curriculum Studies, 40 (4), 417-56.

Karmon, A. (2007) '"Institutional organization of knowledge": The missing link in educational discourse'. Teachers College Record, 109 (3), 603-34.

Klafki, W. (1998) 'Characteristics of critical-constructive Didaktik'. In Gundem, B.B. and Hopmann, S. (eds) Didaktik and/or Curriculum: An international dialogue. New York: Peter Lang, 307-30.

Klafki, W. (2000) 'Didaktik analysis as the core of preparation of instruction'. In Westbury, I. Hopmann, S. and Riquarts, K. (eds) Teaching as a Reflective Practice: The German Didaktik tradition. Mahwah, NJ: Lawrence Erlbaum Associates, 139-59.

Krüger, R.A. (2008) "The significance of the concepts "elemental" and "fundamental" in didactic theory and practice'. Journal of Curriculum Studies, 40 (2), 215-50.

Künzli, R. (2013) 'Memorizing a memory: Schwab's The Practical in a German context'. Journal of Curriculum Studies, 45 (5), 668-83.

Levine, D.N. (2006) Powers of the Mind: The reinvention of liberal learning in America. Chicago: University of Chicago Press.

Lüth, C. (2000) 'On Wilhelm von Humboldt's Theory of Bildung'. In Westbury, I., Hopmann, S. and Riquarts, K. (eds) Teaching as a Reflective Practice: The German Didaktik tradition. Mahwah, NJ: Lawrence Erlbaum Associates, 63-84.

McKeon, R. (1953) 'Spiritual autobiography'. In McKeon, R. Freedom and History and Other Essays: An introduction to the thought of Richard McKeon. Ed. McKeon, Z.K. Chicago: University of Chicago Press, 3-36.

Reid, W.A. (1980) 'Democracy, perfectability, and the battle of the books: Thoughts on the conception of liberal education in the writings of Schwab'. Curriculum Inquiry, 10 (3), 249-63.

Saha, L.J. and Dworkin, A.G. (eds) (2009) International Handbook of Research on Teachers and Teaching. New York: Springer.

Schwab, J.J. (1962) 'The concept of the structure of the discipline'. Educational Record, 43, 197-205.

Schwab, J.J. (1969) College Curriculum and Student Protest. Chicago: University of Chicago Press.

Schwab, J.J. (1973) 'The practical 3: Translation into curriculum'. School Review, 81 (4), 501-22.

Schwab, J.J. (1978) 'Eros and education: A discussion of one aspect of discussion'. In Schwab, J.J. Science, Curriculum, and Liberal Education: Selected essays. Ed. Westbury, I. and Wilkof, N.J. Chicago: University of Chicago Press, 105-32.

Schwab, J.J. (2013) 'The practical: A language for curriculum'. Journal of Curriculum Studies, 45 (5), 591-621.

Uljens, M. and Ylimaki, R.M. (2017) 'Non-affirmative theory of education as a foundation for curriculum studies, Didaktik and educational leadership'. In Uljens, M. and Ylimaki, R.M. (eds) Bridging Educational Leadership, Curriculum Theory and Didaktik: Non-affirmative theory of education. Cham: Springer, 3-145.

von Humboldt, W. (2000) 'Theory of Bildung'. In Westbury, I., Hopmann, S. and Riquarts, K. (eds) Teaching as a Reflective Practice: The German Didaktik tradition. Mahwah, NJ: Lawrence Erlbaum Associates, 57-61. 
Weniger, E. (2000) 'Didaktik as a theory of education'. In Westbury, I., Hopmann, S. and Riquarts, K. (eds) Teaching as a Reflective Practice: The German Didaktik tradition. Mahwah, NJ: Lawrence Erlbaum Associates, 111-25.

Westbury, I. (2000) 'Teaching as a reflective practice: What might Didaktik teach curriculum?'. In Westbury, I., Hopmann, S. and Riquarts, K. (eds) Teaching as a Reflective Practice: The German Didaktik tradition. Mahwah, NJ: Lawrence Erlbaum Associates, 15-39.

Yates, L. and Collins, C. (2010) 'The absence of knowledge in Australian curriculum reforms'. European Journal of Education, 45 (1), 89-102.

Young, M.F.D. (2008) Bringing Knowledge Back In: From social constructivism to social realism in the sociology of education. London: Routledge.

Young, M. (2009a) 'Education, globalisation and the "voice of knowledge"'. Journal of Education and Work, 22 (3), 193-204.

Young, M. (2009b) 'What are schools for?'. In Daniels, H., Lauder, H. and Porter, J. (eds) Knowledge, Values and Educational Policy: A critical perspective. London: Routledge, 10-18.

Young, M. (2013) 'Overcoming the crisis in curriculum theory: A knowledge-based approach'. Journal of Curriculum Studies, 45 (2), 101-18.

Young, M., Lambert, D., Roberts, C. and Roberts, M. (2014) Knowledge and the Future School: Curriculum and social justice. London: Bloomsbury Academic.

Young, M. and Muller, J. (2013) 'On the powers of powerful knowledge'. Review of Education, 1 (3), 229-50.

Young, M. and Muller, J. (2015) Curriculum and the Specialization of Knowledge: Studies in the sociology of education. London: Routledge. 